$\begin{gathered}\text { EPiC Series in Education Science } \\ \text { Volume 1, 2017, Pages 351-360 }\end{gathered}$
$\begin{gathered}\text { AUBEA 2017: Australasian Universities Build- } \\ \text { ing Education Association Conference 2017 }\end{gathered}$

\title{
ROLE OF REGULATORY FRAMEWORK FOR SUPPORTING CONSTRUCTION INDUSTRY IN INDIA
}

\author{
H. Doloi ${ }^{1}$, D.Week ${ }^{2}$ and Atul Bora ${ }^{3}$ \\ ${ }^{1}$ Senior Lecturer, Smart Villages Lab, The University of Melbourne \\ ${ }^{2}$ Postdoctoral Fellow, Smart Villages Lab, The University of Melbourne \\ ${ }^{3}$ Principal, Assam Engineering College, Assam, India
}

hdoloidunimelb.edu.au

\begin{abstract}
The construction industry has played a significant role in supporting the steady growth of Indian economy over the past. Second only to agriculture, the construction industry constitutes $6 \%$ of GDP. With the rapid rate of urbanisation and increasing liberalisation of the economy, the growth in the housing market is also substantial. Under a single national scheme "Pradhan Mantri Gramin Awaas Yojana (PMGAY)" the Government of India is committing to building over 30 million homes by 2022. To support the growth in the construction industry, an appropriate regulatory framework is crucial.

India is a country with a population of 1.3 billion, residing in 29 States and seven Union territories. Total GDP is over two trillion US dollars, growing at more than 7\% per annum. No single regulatory framework is currently in place. There is a high degree of fragmentation of policies, which therefore does not support standardised practices or quality in construction.

There are many causes of poor construction quality India. Resolving these causes requires an extensive national effort. That effort is made unnecessarily more difficulty by the lack of common national regulations or standards.

The University of Melbourne is engaged in a Smart Villages research project to build capacity in construction management in Assam, one of the North-eastern states of India. This research will report on a comparative analysis between the regulatory frameworks of Australia and India. Based on the comparative reviews of the regulatory policies, and comparing the scale and operating environments of both countries, the presentation will highlight regulatory gaps to be filled, and enforcement practices to be created, if India is to overcome the challenges described above.
\end{abstract}

Keywords: Construction, Regulations, India, Building. 


\section{INTRODUCTION}

Construction is a complex process. Projects have long lead times. Construction is capital and resource intensive, and involves many stakeholders over the long lifecycles. The involvement of many stakeholders in construction projects adds significant challenges to managing the entire lifecycle processes efficiently.

There are many causes of poor construction quality in India: design, detailing, drafting, material selection, poor workmanship, lack of proper inspections, formwork failure, geotechnical failures, technical failures, maintenance failures, ignorance, carelessness, negligence and greed (Masurkar and Attar, 2014). Resolving these causes requires an extensive national effort. That effort is made unnecessarily more difficulty by the lack of common national regulations or standards, meaning that these problems must be solved separately for each of the 29 States and seven Union Territories.

As part of a current three-year project, funded by the State of Assam, India, the authors are engaged with research and development activities with a new research entity "Smart Villages Lab" at the University of Melbourne. One of the elements of the project is to conduct research on housing and infrastructure strategies aimed at improving rural life in Assam. The massive growth of the Indian construction industry over recent decades has stressed the industry across several fronts such as skills, resources, leadership, quality control, regulation and compliance.

One of the most aspirational programs under the and ender a single national scheme "Pradhan Mantri Gramin Awaas Yojana (PMGAY)" the Government of India is committing to building over 30 million homes by 2022. The core of supporting such programs for mass housing and infrastructure provisions is a competent and well-developed construction industry.

As the construction industry is one of the most important industry for supporting employments and economic growths of any nation, it is important to understand the barriers and impediments associated with the industry and stimulating efficiencies. Thus, to support the growth of the construction industry, an appropriate regulatory framework is critical.

By comparing the Indian situation with the Australian construction regulatory regime, this research aims to highlight some of the important issues around the regulatory framework and make a reference to the Indian construction practices. The findings are highlighted in the context of current challenges and opportunities.

\subsection{AUSTRALIAN CONSTRUCTION INDUSTRY}

The construction sector is a significant industry for Australia and represents the second largest sector in the economy. As a result, constraining cost growth and improving productivity has the potential to deliver significant economic benefits nationally. The next instalment of building regulation reform has several options to: reduce the costs of compliance while maintaining health and safety standards; further consolidate consistency in regulatory arrangements across and within jurisdictions; and enhance access to and the utility of key tools needed by users of the building and plumbing control systems to improve outcomes.

A 2012 report by the Centre for International Economics (CIE) found that current building regulatory reforms implemented progressively over the last 20 years are delivering $\$ 1.1$ billion per 
annum in benefits, with an additional $\$ 1.1$ billion per annum in potential benefits yet to be realised. To capture these additional benefits, the next instalment of building regulatory reforms includes:

- enhancing access through a free NCC and improving the document's usebility to broaden understanding and consistency in interpretation;

- reduction in State and Territory departures from the NCC and consolidation of regulation, again to improve national consistency;

- limiting the imposition of higher prescriptive standards for building design and construction than those agreed to nationally through the NCC by other authorities, such as local governments; and

- continued expansion of the NCC to cover all on-site building regulations into a single source document for national consistency and remove unnecessary overlaps in regulation.

\section{AUSTRALIAN CONSTRUCTION REGULATORY FRAMEWORK}

\subsection{The Role of Federal Government}

The role of federal government is exercised through the National Construction Code (NCC) and Australian building codes board. The NCC is given legal effect by relevant legislation in each State and Territory. This legislation prescribes or "calls up" the NCC to fulfil any technical requirements that are required to be satisfied when undertaking building work or plumbing and drainage installations. Each State and Territory's legislation consists of an Act of Parliament and subordinate legislation which empowers the regulation of certain aspects of building work or plumbing and drainage installations, and contains the administrative provisions necessary to give effect to the legislation.

There is currently a drive towards national streamlining of regulations. The NCC is an initiative of the Council of Australian Governments developed to incorporate all on-site building and plumbing requirements into a single code. The NCC sets the minimum requirements for the design, construction and performance of buildings throughout Australia. NCC 2016 was adopted by the States and Territories on 1 May 2016 and is based on performance rather than a prescriptive code with a high flexibility of implementation to foster a buoyant sector.

The $\mathrm{ABCB}$ is required by the Inter-Government Agreement (IGA) to develop a Business Plan annually to ensure that its operations are transparent and accountable (ABCB 2016). The Business Plan reflects the ABCB's commitment to the regulatory reform agenda agreed by Governments. Continuing the emphasis on life safety, the $\mathrm{ABCB}$ is working towards achieving productivity gains and a safer built environment through encouraging a greater use of performance based designs. The $\mathrm{ABCB}$ operates under an Inter-Governmental Agreement between the nine Governments across states and territories in Australia.

\subsection{Implementation at the State level}

Like India, Australia is a federation of states. Each individual state has its own construction regulations and governance framework that act as primary enabling legislation. Each State and Territory's legislation consists of an Act of Parliament and subordinate legislation which empowers the regulation of certain aspects of building work or plumbing and drainage installations. It contains 
the administrative provisions necessary to give effect to the legislation and delegates responsibilities for day to day implementation of the act to local councils.

As shown in Figure 1, the Australian construction industry is regulated at the state levels through four levels of regulation.

- State or territory acts of Parliament (enabling legislation)

- State of territory building regulations

- $\quad$ Federal building regulations - the National Construction Code (NCC)

- Reference documents including Australian standards

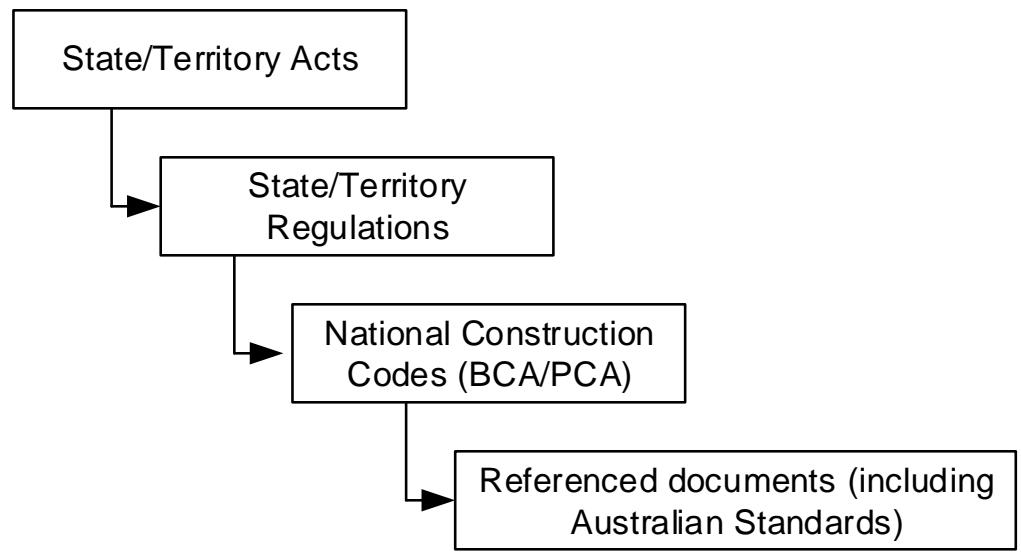

Figure 1 Regulatory levels of Australian Construction Industry

(Source: Australian Government, Building and construction Industry)

\subsection{State Level Governance of Building and Construction - the Victorian context}

Figure 2 depicts the state level regulatory framework in Victoria. As seen, the governance structure is headed by the Ministry of Planning followed by the Victorian Building Authority (VBA) as the key regulatory body (VBA, 2013). Within Victoria an appointed Planning Minister, oversees the role of the Victorian Building Authority (VBA), who regulations act as the primary source of regulations for the state. The VBA is headed by a chief commissioner appointed directly by the Minister for Planning. 


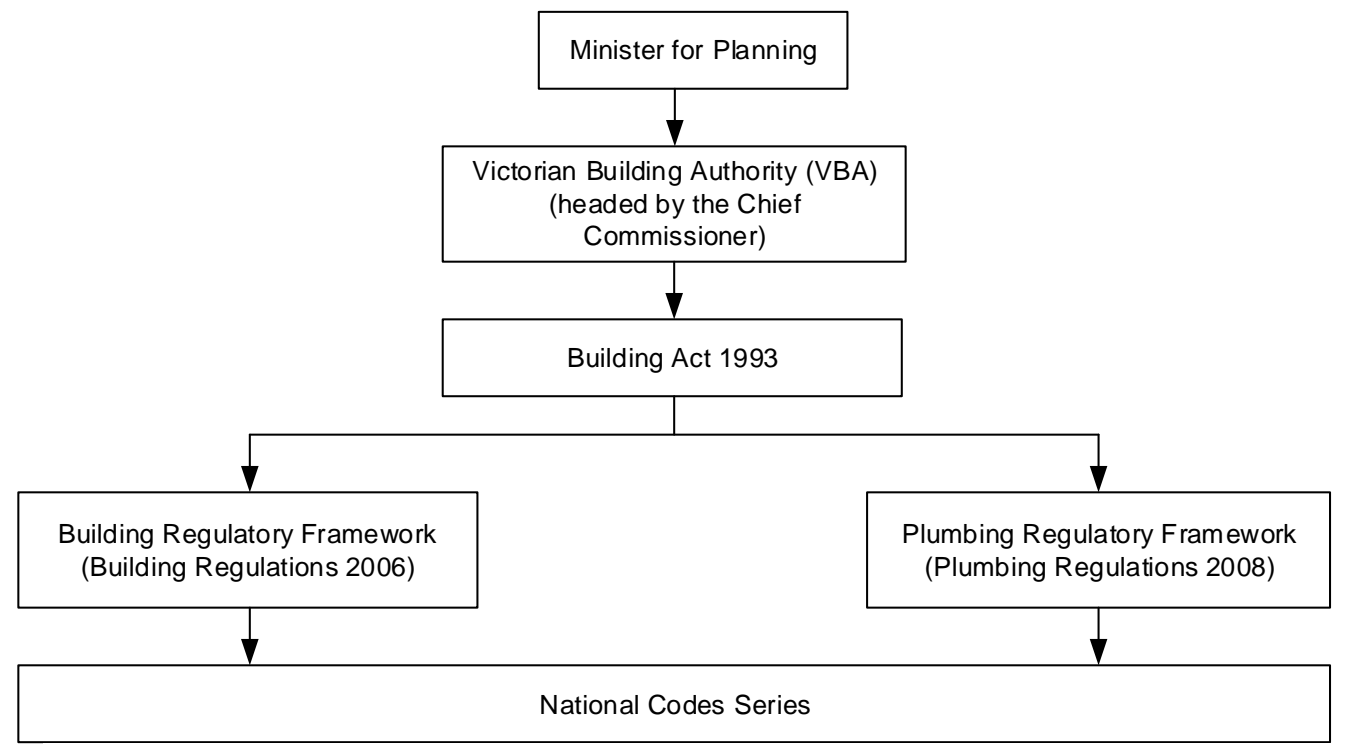

Figure 2 State Level Governance structure (Victorian context)

\subsection{The role of the Building Act (Building Act 1993)}

The Building Act 1993 governs building activity in Victoria. It sets out the legislative framework for the regulation of building construction, building standards and the maintenance of specific building safety features (VBA Website)

The objectives of the Act are:

- to protect the safety and health of people who use buildings and places of public entertainment

- to enhance the amenity of buildings

- to facilitate the adoption and efficient application of national building standards and national plumbing standards

- to facilitate the construction of environmentally and energy efficient buildings

- to aid the achievement of an efficient and competitive building and plumbing industry.

The key function of the Victorian Building Act 1993 includes:

- Regulation of building work and building standards

- Providing the accreditation of building products, construction methods, building components and building systems

- Providing an efficient and effective system for issuing building and occupancy permits and administering and enforcing related building and safety matters and resolving building disputes

- Regulation of building practitioners and plumbers

- Regulation of plumbing work and plumbing standards 
- Providing for the accreditation, certification and authorisation of plumbing work, products and materials

- Limiting the periods within which building actions and plumbing actions may be brought.

\subsection{Key functions of the VBA}

Building registration. Building registration is usually maintained through the Building Practitioners Board (BPB). The BPB is an independent statutory body established under the Building Act 1993. It oversees the quality and standard of professional services in the Victorian building industry. In doing so, it administers a registration system and monitors the conduct and ability of registered building practitioners.

Victoria's Building Regulations 2006 define nine categories of building practitioner. The categories are: Building Surveyor (Unlimited), Building Surveyor (Limited), Building Inspector (Unlimited), Building Inspector (Limited), Quantity Surveyor, Engineer, Draftsperson, Erector or Supervisor (temporary structures), Builder (Commercial Builder and Domestic Builder), and Demolisher.

Building and Planning Permits. While the building permit relates to construction activities in the building (new or existing or extension), planning permit relates to the legal processes associated with the land use or development planning. Thus, a planning permit is a legal document for land use and is usually administered by the planning department of the local council. Building permit is usually administered through the Building Surveyors who could operation in private capacity or as part of the building department of the local council.

Building Appeal Board (BAB). If the building permit is refused by the Building Surveyor and there are differences in opinion between the applicant (as owner of the building) and the building surveyor, then Building Appeal Board may be approached to look into the matter for a independent assessment and providing with a mandate. $\mathrm{BAB}$ is a statutory independent body established under the Building Act 1993. "The BAB is empowered to determine any matter relating to the Building Regulations 2006 (the Regulations), the Building Code of Australia 2006 and specified provisions of the Building Act 1993 (the Act)." (source: VBA Website). 
Violations, enforcements and disputes, are dealt with in a timely manner and depending on scale managed locally or at state level. Claims, appeals, and enforcement are dealt with under Sections 810 of the 1993 Act. Clear and transparent liabilities for each of the parties are stipulated in the legislation. Insurance and warranties are mandatory and transparent and the enforcement takes place at local level for minor claims, District court level with violations and inspections undertaken by local councils. Major violations beyond a threshold are usually dealt with at the state level. Disputes are usually resolved through arbitration to a certain level but beyond that can be escalated to the state court system with a relatively short turnaround times for the processing of cases.

\subsection{CHALLENGES IN THE INDIAN CONSTRUCTION INDUSTRY}

In India, the construction industry is also notionally governed by both federal and state regulations. The Building \& Other Construction Workers (Regulation of Employment \& Conditions of Service) Act, 1996 was enacted to regulate the employment and conditions of service of building and other construction workers and to provide for their safety, health and welfare measures. The Act is applicable to every establishment which employs ten or more workers in any building or other construction work and to the projects costing more than Rs. 10 lakh. The Act contains provision for immediate assistance to the workers in case of accidents; old age pension; loans for construction of house; premium for group insurance; financial assistance for education, medical expenses and maternity benefits, etc. The Act is enforced by local factory inspectorates in Indian states, who also have the power to set their own additional rules under the legislation (Haryana Government website).

In practice however, the regulations are rarely enforced in Indian. Large section of the workforce remains outside the legislations scope in Indian construction industry. More than $90 \%$ of India's workforce falls outside the scope of the Factories Act, the main piece of safety legislation. Health and safety laws are poorly enforced. Regulators are chronically under-resourced. For instance, one factory inspector for every 506 registered factories is a published figure (CIDC, 2010). Data collection on the incidents and reporting is very poor (CIDC, 2010). In the absence of effective government regulations many multinationals are driving their own safety efforts (Sawhney et al 2014).

Unlike Australia, the bureaucracy in India does not foster entrepreneurship in the sector and this is due to the non-existence of any enabling framework across the whole sector (Shirur and Torga, 2014). Obtaining building permits accounts for a large proportion of total construction costs and the process of obtaining building approval is lengthy. Anecdotally, there are numerous references made to rampant corruption while issuing building permits across the country.

To address some of the issues with the issuance of building permits, the Government of Assam has recently made some changes to the process. For instance, the Government of Assam has mandated that in Guwahati, the approval must be given within 75 days from the date of submission of applications. Areas outside metropolitan Guwahati should issue approvals within 60 days of submission. Absence of response within the stipulated timeframe will be deemed as approved. To address the inefficiencies in the building act, two major building construction bylaws have also been put in place: the Guwahati Building Construction (Regulation) Bye-Laws, 2014 and the Assam Notified Urban Areas (other than Guwahati) Building Rules, 2014. These bylaws are designed to expedite permit approval for both individuals and the state. 


\subsection{COMPARATIVE ANALYSIS}

Having reviewed the regulatory framework and the practice of construction, the findings suggests that the Victorian and Assamese regulatory regimes differ in at least in five key ways:

1. Unlike Victorian 4-tier governance, Assam does not have anything comparable: The governance of construction Australian construction industry at the state level is considered to have a good basis for providing necessary support to the industry for growth and development. The existence of such a multi-tire framework provides a clear division of responsibility sharing and enforcing necessary policies and processes for streamlining the construction activities with a high quality output.

2. The local government in Assam is almost defunct in terms of planning and regulatory support at the ground level: Referring to the Assamese practices, there is no any dedicated governance framework for enforcing the planning and regulatory support within the sector. The nonexistence of any framework eventually results in sub-standard practices without promoting any competition within the industry. How the industry is complying to the construction specifications from planning to delivery and operations are currently not possible to evaluate without any authoritative hierarchy within the state. Without an appropriate regulatory body and appropriate implementation processes in place, standardisation of construction practices for high quality output is almost impossible especially in the private projects. While the public projects are somehow regulated through the public agencies such as Public Works Department (PWD), for supporting the private sector, a proper regulatory framework is absolutely required in Assam.

3. Mandatory planning requirements across all tiers of governance: While the district level Town Planning department oversee most of the urban development, there are not any mandatory planning requirements semi-urban and rural areas in the current practices in Assam. Unlike Victorian practice of stricter enforcement of planning especially at the local government level for suburban developments, lack of any mechanism for controlling the planning issues especially outsides of the city boundaries does not promote any quality construction practice in Assam. This eventually triggers the sub-standard building specifications including noncompliance of national codes for materials specifications and construction processes in Assam.

4. The is no such separate requirements for building permit, planning permit and the role of building surveyors are not exists at all in Assam: Unlike Victorian practice for enforcing specific requirements of planning and building permits for new or existing developments, there is no any demarcations of permits in Assamese construction practice. The professional roles and responsibilities of the building practitioners as specified by the Victorian Building Authority are not recognised in the Assam governance system. Thus, there are issues around the core expertise and accountability of the profession for maintaining a high quality output in the sector. 


\section{CONCLUSIONS}

Having reviewed the construction related challenges around the Smart Villages projects in Assam, this research compared the governance framework of Assam in relation to the Victorian practices. The Victorian framework is found to be well developed for supporting growths and development of Australian construction industry. However, the current governance framework in Assam is found to be quite inadequate for meeting the growing challenges in housing and infrastructure sectors especially in the rural construction contexts. There is a clear requirement for an improved framework to support the construction industry and address the challenges of substandard construction across the state.

While the Australian 4-tier governance framework is considered to be effective for supporting growth and development in the sector, the non-existence of any comparable system in Assamese context is certainly not helping for the industry to be ready for the required challenges in the emerging market. However, the opportunities afforded by the new regulations in Assam are promising in terms of cutting down the red tape and reducing the inefficiencies across the sector. While the approval of permit times has notionally being shortened, to foster an industry to a comparable level as of the Australian construction sector, it is suggested that a four-tier framework similar to that of Victoria could be investigate. Such a framework, which includes both local legislation and national standards, allows the state to foster common standards while at the same time maintaining State autonomy in accordance with the Indian constitution.

While the scope of the research is limited in the review of the Australian practices and comparison that to an Indian context, it is expected that the observations drawn from the literature will be of interest to the audience of the conference and likely generate discussion. 


\section{REFERENCES}

$\operatorname{ABCB}(2016)$ http://www.abcb.gov.au/Resources/Publications/Corporate/ 2016-17-Business-Plan. Building Act 1993, VBA Website: http://www.vba.vic.gov.au/practitioners/ legislation CIDC (2010), Construction Industry Development Council, Established by Planning Commission (Government of India) and the Construction Industry

GoI (2015) (https://data.gov.in/keywords/construction http://www.vba.vic.gov.au/practitioners/legislation http://www.australia.gov.au/information-and-services/business-and-industry/building-andconstruction-industry

http://www.abcb.gov.au/Resources/Publications/Corporate/The-Next-Instalment-ofBuilding-Regulation-Reform

Masurkar, Y. S., Attar, A. C. (2014). Investigating the Causes for Failures in Construction by Taking a Case Study. Current Trends in Technology and Science. ISSN: 2279- 0535. Volume: 3, Issue: 5 (Aug-Sept. 2014)

Sawhney A., Agnihotri, R and Paul, V, (2014) "Grand challenges for the Indian construction industry", Built Environment Project and Asset Management, Vol. 4 Issue: 4, pp.317-334.

Shirur, S. and Torga, S. (2014), Indian Construction Industry: Challenges for the Construction Managers, IOSR Journal of Business and Management (IOSRJBM), Volume 16, Issue 4. Ver. III (Apr. 2014), PP 65-66.

VBA (2013), Building and Construction Industry Security of Payment Regulations 2013. 